\title{
FOREWORD
}

\section{Living with Snakes}

Harry W. Greene

$\mathrm{T}^{1}$ he roughly 2700 species of extant serpents range from tiny, parthenogenetic Flowerpot Blindsnakes (Ramphotyphlops braminus) to giant Green Anacondas (Eunectes murinus), from gentle Rosy Boas (Charina trivirgata) to deadly venomous Taipans (Oxyuranus scutellatus). Snakes inhabit terrestrial, aquatic, arboreal, fossorial, and marine environments, and eat animals as diverse as fish eggs, slugs, and porcupines. In addition to their important roles in natural ecosystems, serpents interact with humans in diverse ways, some "good" and some "bad," and that's where things get murky in terms of conservation. In this brief essay I affirm the necessity for management in a world that is nowhere truly pristine, underscore the many positive roles snakes play in nature and in human affairs, and emphasize some lessons learned from efforts to control snakes on Pacific islands.

By the end of this century 6 billion humans will burden the earth, and the devastating impact of our expanding population on biological diversity is increasingly evident. In the face of this catastrophe, however, only about $10 \%$ of the world's snake species receives special protection, a fraction that grossly underestimates the number actually threatened with extinction. Beyond the fact that dozens of snakes are known only from type specimens (e.g., 7 species in Sri Lanka alone), the conservation status of most species of serpents has not yet been evaluated. In Europe, where the snake fauna is small and relatively well studied, 19 of 27 species need active management; in contrast, the conservation status of almost all of the hundreds of species of Asian snakes is virtually unknown. Sustained persecution, habitat destruction, and restricted geographic distributions imply that perhaps $60 \%$ or more of 157 species of pitvipers are now threatened or endangered, but only about a dozen species in that group are formally singled out for protection. In fact, many snakes may be especially vulnerable to extinction because of their slow growth rates, small clutches, and infrequent reproductioncomponents of a general life history syndrome that hinges on high adult survivorship (Dodd, 1987, 1993; Greene and Campbell, 1992; Scott and Seigel, 1992).

Blatant antisnake programs were routine earlier in this century, when similarly hostile attitudes prevailed even toward large mammalian predators. A book on Pennsylvania snakes written at that time says of the Copperhead (Agkistrodon contortrix), "there is no creature more treacherous, despicable nor dangerous" 
(Surface, 1906), and Boy Scouts of the 1930s won special "conservation" medals for killing Northern Watersnakes (Nerodia sipedon), in the mistaken view that they were enhancing trout populations (Anon., 1938). Even in the 1970s, visitors at a national park in the United States overwhelmingly supported protection of "all wildlife," but were in much less agreement about whether or not snakes should be killed in the park (Burghardt et al., 1972). Nevertheless, even granting widespread negative attitudes toward serpents, the present volume might seem paradoxical in the current climate of enlightened, conservation-minded biology. After all, efforts are under way in Europe and North America to conserve various snakes, but the authors of this book are concerned mainly with destroying snakes, or at least controlling their populations.

Widespread mythology notwithstanding, we have been managing animal and plant populations for many thousands of years, and humans exterminated many species of vertebrates long before Europeans explored and colonized the globe (Nabhan, 1995; Steadman, 1995). Some snake populations warrant active management and sometimes even local extermination, for two broad classes of reasons. First, habitat destruction and human persecution threaten certain populations and even entire species with extinction, and their rescue may require some kind of intervention. In such cases, management might be controversial because of widespread antipathy toward snakes (if the merit of saving them is questioned) or because of a "hands-off" attitude toward conservation. Second, a few species of serpents cause problems for natural communities or human welfare. The Brown Treesnake (Boiga irregularis) is the only dramatic example of an artificially introduced snake causing widespread ecological damage, but clearly the potential exists for other such incidents. Perhaps 500 species of colubrids, atractaspidids, elapids, and viperids are potentially dangerous to humans; of those, about 50 species cause most snakebite accidents and fatalities, and today they remain serious public health problems in some tropical regions (e.g., Russell's Viper, Daboia russelli, is responsible for about 1000 bites per year in Burma, and snakebite is the fifth most important cause of death in that country; see Warrell, 1989, 1991). Programs to conserve snakes and their habitats will not succeed unless these safety issues are successfully addressed, and the studies on Habu (Trimeresurus flavoviridis) summarized in this book exemplify ways in which a serious snakebite problem can be confronted by active, well-informed management.

In addition to controlling or even eliminating problem snake populations, conservationists must stress public education and ways we can live with these animals. Given the emphasis in this book, I take this opportunity to underscore the many significant roles serpents play in their environments and in our lives. Many snakes eat proportionately very large items, and some serpents are competitors with and even prey on fairly large birds and mammals. Snakes are models for several insect mimicry systems (Pough, 1988), influence the evolution of nesting and 
social adaptations in birds (Jackson, 1974; Greene, 1989), and interact in diverse other ways with their ecological assemblages.

For those who require utilitarian reasons to justify conservation, nature is essentially an enormous testing laboratory, in which over hundreds of millions of years organisms have developed solutions to countless environmental challenges. Accordingly, a component of pitviper venom, perhaps evolved for immobilizing or digesting prey, now is synthesized as a multimillion-dollar drug for high blood pressure (Ferguson et al., 1984). The shaker muscle of rattlesnake tails has several unique properties related to its natural defensive role and serves as a model system for studying muscle molecular physiology (Conley and Lindstedt, 1996; Schaeffer et al., 1996), in turn a prerequisite for developing cures for some diseases.

From an aesthetic perspective, humans' fascination with snakes is famously ambiguous, reflecting both fear and curiosity-perhaps in part because primates have both eaten and been killed by serpents since long before the origin of hominids (I explore these issues in more detail elsewhere; Greene et al., 1997; and also Kellert and Wilson, 1993). In any case, snakes haunt and inspire us, provoking outlandish legends, rational fears, and admiration. Even venomous snakes embody scaly symmetry and harmonious colors, and walking in their habitats fosters a special kind of respect for nature, an urgency that both humbles and enlivens us.

Snakes offer some special lessons for conservation. First, these animals are especially problematic with respect to human attitudes, as evidenced by the persistence of rattlesnake roundups and other blatantly inhumane spectacles (Arena et al., 1995). If we can mobilize people to tolerate and even care about snakes, especially venomous species, then conserving vultures and badgers will be easy (for a particularly thorough account of the problems of conserving a venomous snake, see Brown, 1993). Second, management is inevitable if we are to preserve significant portions of the earth's existing biotas, and management depends on science (Dodd and Seigel, 1991; Reinert, 1991). As repeatedly shown by the case studies in this book, decades of descriptive natural history studies underlie these activities (see also Greene, 1989, 1994). We especially need sustained monitoring of many animal and plant populations, yet support for such activities is widely available only for certain songbirds, raptors, and game species. There are woefully few mechanisms to sustain basic research on biological diversity, and everyone committed to conservation, from lay naturalists to leaders of environmental organizations, should work toward solving this problem. Third, and perhaps most important, the complex plight of snakes recalls other creatures that are dangerous (e.g., sharks [Manire and Gruber, 1990]), secretive (e.g., velvet worms [New, 1995]), unpopular (e.g., centipedes), and relatively poorly studied. These animals remind us that we seriously underestimate the extent to which species and even entire natural communities are endangered-that in fact, a global biodiversity crisis is well under way. 


\section{ACKNOWLEDGMENTS}

H. K. Reinert alerted me to the comment by Surface; D. L. Hardy Sr., G. H. Rodda, and K. R. Zamudio provided helpful comments on the manuscript.

\section{LITERATURE CITED}

Anon. 1938. For better fishing-kill the watersnake. Pennsylvania Board of Fish Commissioners, Combined Biennial Report [no volume], 71-75.

Arena, P. C., C. Warwick, And D. Duvall. 1995. Rattlesnake round-ups. In R. L. Knight and K. Gutzwiller, eds., Wildlife and Recreationist: Coexistence through Management and Research, pp. 313-324. Washington, D.C.: Island Press.

Brown, W. S. 1993. Biology, status, and management of the timber rattlesnake (Crotalus horridus): A guide for conservation. Herpetol. Circ. 22:1-72.

Burghardt, G. M., R. O. Hietala, and M. R. Pelton. 1972. Knowledge and attitudes concerning black bears by users of the Great Smokey Mountains National Park. In S. Herrero, ed., Bears-Their Biology and Management, pp. 255-273. Morges, Switzerland: IUCN.

Conley, K. E., And S. L. Lindstedt. 1996. Minimal cost per twitch in rattlesnake tail muscle. Nature 383:71-72.

Dodd, C. K. JR. 1987. Status, conservation, and management. In R. A. Seigel, J. T. Collins, and S. S. Novak, eds., Snakes: Ecology and Evolutionary Biology, pp. 478-513. New York: Macmillan.

- 1993. Strategies for snake conservation. In R. A. Seigel and J. R. Collins, eds., Snakes: Ecology and Behavior, pp. 478-513. New York: McGraw-Hill.

Dodd, C. K. JR., AND R. A. Seigel. 1991. Relocation, repatriation, and translocation of amphibians and reptiles: Are they conservation strategies that work? Herpetologica 47:336-350.

Ferguson, R. K., P. H. Vlasses, And L. J. Riley. 1984. Captopril in the treatment of hypertension and congestive heart failure. Res. Staff Physician 30(11):PC24-28.

Greene, H. W. 1989. Ecological, evolutionary, and conservation implications of feeding biology in Old World cat snakes, genus Boiga (Colubridae). Proc. Calif. Acad. Sci. 46:193-207.

- 1994. Systematics and natural history, foundations for understanding and conserving biodiversity. Am. Zool. 34:48-56.

Greene, H. W., and J. A. Campbell. 1992. The future of pitvipers. In J. A. Campbell and E. D. Brodie Jr., eds., Biology of the Pitvipers, pp. 421-427. Tyler, Tex.: Selva.

Greene, H. W., M. Fogden, And P. Fogden. 1997. Snakes: The Evolution of Mystery in Nature. Berkeley: Univ. California Press.

JACkson, J. A. 1974. Gray Rat Snakes versus Red-cockaded Woodpeckers: Predatorprey adaptations. Auk 91:342-347.

Kellert, S. R., And E. O. Wilson, eds. 1993. The Biophilia Hypothesis. Washington, D.C.: Island Press.

Manire, C. A., And S. H. Gruber. 1990. Many sharks may be headed toward extinction. Conserv. Biol. 4:10-11. 
NaBhan, G. P. 1995. Cultural parallax in viewing North American habitats. In M. Soulé and G. Lease, eds., Reinventing Nature? Responses to Postmodern Deconstructionism, pp. 87-101. Washington, D.C.: Island Press.

New, T. R. 1995. Onycophora in invertebrate conservation: Priorities, practice and prospects. Zool. J. Linn. Soc. 114:77-89.

Pough, F. H. 1988. Mimicry and related phenomena. In C. Gans and R. B. Huey, eds., Biology of the Reptilia. Vol. 16, Ecology B, Defense and Life History, pp. 153-234. New York: Alan R. Liss.

ReInert, H. K. 1991. Translocation as a conservation strategy for amphibians and reptiles: Some comments, concerns, and observations. Herpetologica 47:357-363.

Schaeffer, P. J., K. E. Conley, And S. L. Lindstedt. 1996. Structural correlates of speed and endurance in skeletal muscle: The rattlesnake tailshaker muscle. J. Exp. Biol. 199:351-358.

Scott, N. J., AND R. A. Seigel. 1992. The management of amphibian and reptile populations: Special priorities and methodological and theoretical constraints. In D. R. McCullough and R. H. Barrett, eds., Wildlife 2001: Populations, pp. 343-367. London: Elsevier.

Steadman, D. W. 1995. Prehistoric extinctions of Pacific island birds: Biodiversity meets zooarchaeology. Science 267:1123-1131.

Surface, H. A. 1906. The serpents of Pennsylvania. Mon. Bull. Pa. Dept. Agric. 4.

WARRELL, D. A. 1989. Snake venoms in science and clinical medicine 1. Russell's Viper: Biology, venom and treatment of bites. Trans. Roy. Soc. Trop. Med. Hyg. 83:732-740.

. 1991. Snakes. In G. T. Strickland, ed., Hunter's Tropical Medicine, pp. 877-888. Philadelphia: W. B. Saunders. 

PROBLEM SNAKE MANAGEMENT 
